\title{
First record of human trichinosis in Chile associated with consumption of wild boar (Sus scrofa)
}

\section{Enrique García, Lidia Mora, Patricio Torres/ ${ }^{+}$, Maria Isabel Jercic*, Rubén Mercado**}

\author{
Instituto de Parasitología, Facultad de Medicina, Universidad Austral de Chile, Casilla 567, Valdivia, Chile *Laboratorio de \\ Referencia en Parasitología, Instituto de Salud Pública de Chile, Santiago, Chile **Instituto de Ciencias Biomédicas, Facultad de \\ Medicina, Universidad de Chile, Santiago, Chile
}

The first South American case of human trichinosis, resulting from the consumption of roast wild boar (Sus scrofa) is reported in Chile. The patient presented fever, diarrhea, myalgias, facial edema, sub-conjunctival reddening, photophobia, eosinophilia, and elevated glutamic oxalacetic transaminase. The diagnosis was confirmed by two immunoenzymatic tests (ELISA) using somatic and excretion-secretion antigens.

Key words: human trichinosis - wild boar - Sus scrofa - Chile

Trichinosis or trichinellosis, caused by the nematode Trichinella spiralis, is cosmopolitan in distribution, and represents the most frequent food-transmitted helminth zoonosis (Neafie et al. 2000). At present, human and animal trichinosis is considered as an emerging infection due to the increase in its prevalence in countries such as Bulgaria, Rumania, Yugoslavia, Croatia, Lithuania, Russia, China, Argentina, and Mexico (Pozio 2001). It is also considered to be a re-emergent infection since epidemiological and biological research on its life cycle in the wild life have led to the description of new species in various regions with new patterns of transmission, which increase the risk of human infection from consumption of the meat of wild animals (for example in Canada, United States, Russia, and Lithuania), or domestic animals such as the horse (in France and Italy) or dog (in China) (Fayer 2000, Pozio 2001). Decrease in human and porcine manifestation of this infection is reported in Chile between 1991 and 2000 (Schenone et al. 2002). Trichinosis has not been previously reported from wildlife in South American countries except for Argentina (Neghme \& Schenone 1970). The objective of this communication is to present the first record of human trichinosis in South America associated with the consumption of meat of the introduced wild boar (Sus scrofa), in Chile.

\section{Clinical case}

The patient (DOD) was a 36 year old male laborer from a rural property, community of Futrono, Chile $\left(40^{\circ} 05^{\prime} \mathrm{S}\right.$; $\left.72^{\circ} 22^{\prime} \mathrm{W}\right)$, who was first attended on 2 June 2004 . The

Partial financial support: Dirección de Investigación y Desarrollo, grant S-200405

${ }^{+}$Corresponding author. E-mail: ptorres@uach.cl

Received 6 October 2004

Accepted 15 December 2004 patient reported symptoms of fever, diarrhea, and myalgias beginning on 20 May 2004. The myalgias were acute in the deltoid, thigh, and lumbar regions. Facial edema, particularly in the periocular and lower regions was also found. Clinical examination of mouth and pharynx was normal. Ocular examination showed discrete subconjunctival reddening, which, according to the patient, was intense and accompanied by photophobia that lasted about one week. The patient reported the consumption of meat from a wild boar on the 1st May. The boar was hunted in the rural region near where the patient lived, and the meat was consumed in a lightly roasted condition. In the initial consultation, the patient complained only of muscular pain and fatigue, without fever, and blood tests (hemogram and erythrocyte sedimentation rate) were ordered. Examination after $48 \mathrm{~h}$ showed persistence of muscular pains and an eosinophilic leucocytosis of $34 \%$, plus an elevated seric glutamic oxalacetic transaminase (GOT). These results suggested a diagnosis of trichinosis, and treatment was initiated using anti-inflammatories, analgesics, corticoids, and analgesic eyewash. Thirty days after ingestion of the meat of the wild boar, serum from the patient was obtained and sent to the Reference Laboratory of the Institute of Public Health of Chile (ISP) for serological examination. Immunoenzymatic tests (ELISA) were made on the serum, one employing a somatic antigen made from first stage Trichinella spiralis larvae (L1) isolated from muscle tissue and standardized at the ISP. A second test was performed using commercially obtained reagents containing somatic and excretion-secretion antigens of L1 (LDM Laboratories, California, US). The optical density observed using the ISP antigen was 0.639, while that obtained with the commercial reagent was 0.920 . Both tests far the exceeded requirement for a positive result $(\mathrm{OD}=0.3)$. Results of the diagnostic findings were reported to the Department of Environmental Protection, National Health Service, in Valdivia province. The patient was re-examined on 17 July, showing few painful symptoms and no further symptomatology. A new hemogram showed decrease of the eosinophilia to $19 \%$. In a final 
examination, four days later the patient was discharged as asymptomatic.

This was the first case of human trichinosis associated with consumption of meat of the wild boar, introduced in South America. At present 8 species of Trichinella are known, including T. spiralis, T. nativa, T. britovi, T. murrelli, and T. nelsoni in mammals, $T$. pseudospiralis in birds, and $T$. papuae and $T$. zimbabwensis in reptiles. The latter three species can also develop in mammals (Pozio et al. 2004). T. murreli, T. nativa, T. spiralis, T. pseudospiralis, T. britovi, and T. nelsoni can develop in humans. Cases are also recorded from consumption of crocodile meat infected by an unidentified Trichinella species (Mukaratirwa \& Foggin 1999).

Wild boars were initially introduced around 1904-1906, supposedly from Siberia to the La Pampa Province of Argentina (Jaksic et al. 2002). Some of these were transported between 1917 and 1922 to the Province of Neuquen. Boars escaped their confines and disseminated into the Nahuel Huapi and Lanín Parks (Rio Negro Province, Argentina) from where it is assumed they migrated into Chile between 1920 and 1930 (Jaksic et al. 2002), where they are now distributed between $36^{\circ}$ and $47^{\circ} \mathrm{S}$.

Wild boars have been mentioned as hosts for trichinosis in Russia (Mel'nikova 1968) and other european countries (Acha \& Szifres 2003). In Spain, the prevalence of trichinosis infection ranges between 1 and $11 \%$ in these pigs, causing almost $50 \%$ of human infections (Martínez-Fernández 2001). The disease may have been brought to South America with infected animals at the time of their establishment in Argentina and Chile, or acquired by them through ingestion of small infected mammals or their carcasses. Encysted larvae of T. spiralis may remain infective within rodent carcasses for almost two months under environmental conditions prevalent in Southern Chile (Barrientos \& Torres 1982). No studies have been made on the parasites of wild boars in Chile, in spite of their importance in the transmission of various parasites (Fernández de Mera et al. 2003, SolaymaniMohammadi et al. 2003). The gray fox, Pseudolopex gracilis, which is native to Chile and Argentina (Jaksic et al. 2002), has also been mentioned as a host for trichinosis in Argentina, as well as the armadillo (Chaetophractus villosus) and the rodent Graomis griseaflavus (Neghme $\&$ Schenone 1970). The results of the present study reiterate the importance of continued study of native and introduced wildlife in the determination of their potential roles in the transmission of infections of importance to public health, as well as the possibility that natural cycling of trichinosis occurs within the wildlife in Southern Chile.

\section{REFERENCES}

Acha PN, Szifres B 2003. Zoonosis y enfermedades transmisibles comunes al hombre y a los animales, Organización Panamericana de la Salud, Publicación Científica y Técnica 580, Washington, $413 \mathrm{pp}$.

Barrientos J, Torres P 1982. Sobrevida y capacidad infectante de Trichinella spiralis en el macro ambiente. Rev Med Chile 110: 1059-1062.

Fayer R 2000. Global change and emerging infectious disease. J Parasitol 86: 1174-1181.

Fernández de Mera IG, Cortazar C, Vicente J, Hofle U, Fierro Y 2003. Wild boar helminths: risks in animal translocations. Vet Parasitol 115: 335-341.

Jaksic FM, Iriarte JA, Jiménez JE, Martínez DR 2002. Invaders without frontiers: cross-border invasions of exotic mammals. Biol Invas 4: 157-173.

Martínez Fernández AR 2001. Triquinelosis. In EM Cordero del Campillo, FA Rojo Vásquez (eds), Parasitología Veterinaria, McGraw-Hill Interamericana, Madrid, p. 496506.

Mel'nikova TG 1968. Some information on the helminth fauna of the boar (Sus scrofa nigripes) in Tadzhikistan. In ND Levine, Natural Nidality of Diseases and Questions of Parasitology, University of Illinois Press, Chicago, p. 200-202.

Mukaratirwa S, Foggin CM 1999. Infectivity of Trichinella sp. isolated from Crocodylus niloticus to the indigenous Zimbabwean pig (Mukota). Int J Parasitol 29: 1129-1131.

Neafie RC, Marty AM, Andersen EM 2000. Trichinosis. In WM Meyers, Pathology of Infectious Diseases Vol. I, Helminthiases, Armed Forces Institute of Pathology, American Registry of Pathology, Washington, p. 471-480.

Neghme A, Schenone H 1970. Trichinosis in Latin America. In SE Gould, Trichinosis in Man and Animals, Charles C Thomas Publisher, Illinois, p. 407-422.

Pozio E 2001. New patterns of Trichinella infection. Vet Parasitol 98: 133-148.

Pozio E, Marucci G, Casulli A, Sacchi L, Mukaratirwa S, Foggin CM, La Rosa G 2004. Trichinella papuae and Trichinella zimbabwensis induce infection in experimentally infected varans, caimans, pythons and turtles. Parasitology 128: 333-342.

Schenone H, Olea A, Contreras MC, Mercado R, Sandoval L, Pavletic C 2002. Situación epidemiológica actual de la triquinosis en Chile, 1991-2000. Rev Med Chile 130: 281285.

Solaymani-Mohammadi S, Mobedi I, Rezaian M, Massoud J, Mohebali M, Hooshyar H, Ashrati K, Rokni MB 2003. Helminth parasites of the wild boar, Sus scrofa, in Luristan province, Western Iran and their public health significance. J Helminthol 77: 263-267. 